Article

\title{
Nightclub as a Liminal Space: Space, Gender, and Identity in Lisa See's China Dolls
}

\author{
Melody Yunzi Li (i) \\ College of Liberal Arts and Social Sciences, University of Houston, Houston, TX 77204-3006, USA; \\ mli40@central.uh.edu
}

Received: 14 November 2018; Accepted: 26 November 2018; Published: 29 November 2018

\begin{abstract}
Nightclubs flourished in San Francisco's Chinatown in the late 1930s when it became a nightlife destination. To Chinese Americans, however, San Francisco nightclubs became a new site at the time for them to re-explore their identities. For some, visiting these nightclubs became a way for them to escape from traditional Chinese values. For others, it became a way to satisfy Western stereotypes of Chinese culture. Lisa See's China Dolls (2015) describes three young oriental women from various backgrounds that become dancers at the popular Forbidden City nightclub in San Francisco in the late 1930s. Through the three girls' precarious careers and personal conflicts, Lisa See proposes the San Francisco nightclub as both a site for them to articulate their new identities beyond their restricted spheres and a site for them to perform the expected stereotypical Asian images from Western perspectives. It was, at that time, a struggle for the emergence of modern Chinese women but particularly a paradox for Chinese-American women. The space of the Chinese-American nightclub, which is exotic, erotic, but stereotypical, represents contradictions in the Chinese-American identity. Through studying Lisa See's novel along with other autobiographies of the Chinese American dancing girls, I argue that San Francisco nightclubs, as represented in Lisa See's novel, embody the paradox of Chinese American identities as shown in the outfits of Chinese American chorus girls-modest cheongsams outside and sexy, burlesque costumes underneath.
\end{abstract}

Keywords: nightclub; Chinatown; San Francisco; China Dolls; Lisa See; dancing girls

The recent popularity of Crazy Rich Asians (2018), which is a romantic comedy produced in America with an all-Asian cast, raises a number of issues that constantly reappear in Asian American cultures including stereotypes of Asians and the East-West cultural clash. Yet unlike previous Hollywood productions that include Asians or Asian Americans as ancillary characters or in the context of inter-racial relationships, this film focuses on the Asian Americans and Asians themselves instead of inter-racial relationships. When Rachel Chu convinces her traditional mother-in-law that she, a liberal Asian-American woman who pursues her own passions and love interests, can be "enough" for the rich Nick, she also crosses the barriers of what this mother-in-law and the traditional family consider as a perfect wife, by proclaiming that Asian Americans, neither fully accepted by Asians or Americans, standing as in-between, can form their own powerful culture and identity. Rachel's success indicates that the authenticity of the Chinese identity is irrelevant. Similarly, the main protagonist and narrator Grace in Lisa See's China Dolls are annoyed by the question of authenticity and stereotypes. Both Rachel and Grace call for a rethinking of the Asian-American identity.

Lisa See's China Dolls (2015) portrays similar recurrent issues as Crazy Rich Asians in the Asian American communities-conflicts between Eastern and Western cultures, between Asian traditions and the freedom of America, gender and racial differences, Asian stereotypes in American society, Orientalism, etc. All these issues are well-addressed in existing scholarship even if not quite emphasized to a sufficient degree. While Asian American and the diaspora scholarship often focuses 
on displacement and dislocation, researchers spend much less time on the concepts of space and place. ${ }^{1}$ Yet space and place are strongly tied up with social constructions of gender and racial identities and are, thus, worth studying. A few literary studies examines Chinatown depicting it either as a social space of legal discrimination ( $\mathrm{Xu}$ 2015) or as an urban setting for Asian Americans to reimagine their identities. ${ }^{2}$ Following Xiaojing Zhou's study, which critically stages Chinatown as a space for Asian Americans, this paper aims to further contribute to the study of space in Asian American literature by studying space, gender, and identity in China Dolls.

China Dolls describes three young Oriental women from various backgrounds who become dancers at the popular Forbidden City nightclub in San Francisco in the late 1930s, which featured Asian American singers, dancers, chorus lines, magicians, and musicians. Grace Lee is an American-born Chinese girl growing up in the Midwest. She dominates the narrative of the novel and leads a fruitful life and career. Helen Fong grows up in her traditional Chinese courtyard in Chinatown. Ruby Tom is a Japanese American that is crowned as a Chinese princess in the dance club. Through the three girls' precarious careers and personal conflicts, Lisa See proposes the San Francisco nightclub as both a site for them to re-articulate their new identities beyond the restricted spheres from their upbringing or tradition and a site for them to perform the expected, stereotypical Asian images from Western perspectives. It was, at that time, a struggle for the emergence of modern Chinese women but particularly a paradox for Chinese-American women. The space of the Chinese-American nightclub, which is exotic, erotic, and stereotypical, provides certain freedoms and represents the contradictions in the Chinese-American identity. Through studying Lisa See's novel along with other autobiographies of the Chinese-American dancing girls, I argue that San Francisco nightclubs, as represented in Lisa See's novel, embody the paradox of Chinese-American identities as shown in the outfits of Chinese-American chorus girls-modest cheongsams outside and sexy burlesque costumes underneath.

The following few paragraphs outline the structure of the essay. I start from the common conception of nightclub as an exploitative space and show that the Chinatown nightclub confirms this perception. Then I illustrate that nightclub can be a relative space of freedom that allows the dancing girls to pursue their own identities, rendering it into a space for independence and artistic freedom. Yet this space also contains its own limitations, which are circumscribed by both personal choices and larger societal pressures. Therefore, I conclude that nightclub is a complex, paradoxical space for the dancing girls.

The dancing girls in Chinatown nightclubs have commonly been seen as sexualized objects. In this way, their bodies and the space in which their bodies are displayed are read as spaces of commercialization, Orientalization, and fetishization. As a reporter for the San Francisco Examiner wrote in the 1980s, "Ethnicity, for better or worse, was always part of the act. The performers had to put up with the ignorance of the mainly Caucasian audience" (Seligman 1989). In other words, exoticism was part of what nightclubs were selling. While we can read the nightclub space as a house of stereotypes-a way of packaging racist tropes about Asians for Western consumption, a way of making Asian female bodies exotic in a sexist and racist manner-it also provides a space of reduced restrictions and, thus, a wider stage and space for different conflicts to be played out and dramatized.

I am not denying that the nightclub space partially serves up stereotypes by objectifying Asian women. This, however, runs the risk of preventing us from seeing the other possibilities that the space offered. Here, I am interested in understanding nightclub as an active space in which the performers are able to visualize and negotiate their female identity according to their own wills. In fact, in the foreword of Arthur Dong's book on the famous nightclub Forbidden City, Lisa See claims that these performers

1 Doris Bachmann-Medick points out the emergence of a counter-trend to the largely discussed transit "identities," including "the rediscovery of the local, of home, of connections to a specific place" (Bachmann-Medick 2016, p. 214).

2 Xiaojing Zhou has thoroughly studied urban spaces in American American literature, focusing on the transformative relationship between Chinatown and Chinese American subjectivity. See Cities of Others. Reimagining Urban Spaces in Asian American Literature (Zhou 2014). 
"broke the mold for what an Asian girl could or should do." ${ }^{3}$ See's claim is dramatized through her characters in China Dolls since they all create their own Asian-American identities outside of various restrictions. Nightclubs provide a community to the three main characters in See's novel, which supports them in their efforts to recreate their new identities beyond the original spaces or restriction and trauma from which they escape. Despite the prejudices and difficulties, Chinatown nightclubs overall have less restrictions than the spaces the characters escape from. In addition, nightclubs take the characters beyond their traditional boundaries and across different cities. Geographical adaptivity/fluidity became part of their changing identities. When explaining one of the discourses of positionality, which emphasizes situational approaches, Susan Stanford Friedman points out that "geographic allegorization ... is not merely a figure of speech, but a central constituent of identity" (Friedman 1998, p. 23). I argue that the nightclub is a central constituent of the characters' identities, which are defined through relational, ${ }^{4}$ situational, ${ }^{5}$ and communal relationships. ${ }^{6}$ Through exploring the role of nightclubs in the lives of See's central characters, this paper argues that works such as China Dolls can be empowering for women in marginal positions such as the dancing girls.

Bridges, borderlands, and boundaries have long been recognized as "contact zones," which have been spaces for encounters between people of different races, ethnicities, socio-economic backgrounds, and sexual tendencies. These encounters are often forbidden in other spaces and contexts. These spaces are characterized by active movement, crossings, and migrations. The nightclub, by contrast, looks much more static and yet it still serves a similar function: allowing the Asian female performers to express and formulate their identities at a time when there were more restrictions and barriers through encounters that were not openly acceptable or accessible elsewhere. Therefore, the nightclub operates as a liminal space that allows the intermingling of East and West, self and other, tradition, and modernity. Particularly, in China Dolls, the nightclub becomes a space where barriers are softened and become permeable even during World War II when tension between Japanese, Japanese-Americans, and white Americans became hardened and the animosity towards Asian immigrants was inflamed. This concept may fit into Elijah Anderson's description of nightlife public spaces as "cosmopolitan canopies ... that offer a respite from the lingering tensions of urban life and an opportunity for diverse people to come together" (Anderson 2011, p. xiv). In studying nightclubs in Northeast Georgia, Reuben A. Buford May argues against Anderson by saying that the nightlife produces spaces that are more accurately those of integrated segregation (Buford May 2014). Drawing examples from the separation of nightclub patrons, Buford May argues that the space of nightclubs further entrenches structures of power and oppression that are present in mainstream society. This view shows the conflicts in urban nightlife, which, in China Dolls, find reflection in the racial divides and tensions between the club owners, dancers, and customers. See's novel suggests that Anderson and May are both right-nightclub provides greater freedom and autonomy than the world outside, but it is never completely free of the prejudices and restrictions of the wider world and indeed exploits them. In that way, the nightclub is a paradoxical space of modernity much like the costumes of the Asian and Asian American chorus girls: modest cheongsams outside and revealing burlesque costumes underneath.

Meanwhile, the fluidity and freedom Chinatown nightclubs provide are limited. In the novel, although Helen tries to step out of her traditional courtyard and make a living on her own as a nightclub dancer, in the end, she returns to the maternal role she occupies in her patriarchal family. Nightclub gives Ruby a relatively free and safe space especially when she is considered a dangerous enemy during WWII, but eventually she is still sent down to the internment camp and cannot get

See (Dong 2014, p. 7).

For detailed discussion on the cultural narrative of relational positionality. See (Friedman 1998, pp. 47-50).

Situational identity has not been largely theorized as such in literary studies.

6 Here, I am in line with the spatial turn summarized by Bachmann-Medick: "space as a social production process encompassing perceptions, utilizations and appropriations, a process closely bound up with the symbolic level of spatial representation" (Bachmann-Medick 2016, p. 216). 
away from the nationalist regime. Grace is perhaps the luckiest one: she has made it out of her rural area and finally (for the most part) gets what she wants. Therefore, though it is a relatively liberating space, Lisa See's version of nightclub does illustrate its restrictions and boundaries. The nightclub setting is, therefore, a space of paradox in modernity, as shown in the outfits of Chinese American chorus girls-modest cheongsams outside with sexy burlesque costumes underneath.

\section{1. "We looked delicate and breakable ... like little China Dolls."}

There is no denying that nightclubs of the novel are problematic spaces that exploit the Asian-American female performers' ethnicity and sexuality. Nightclub owners and managers use the performers' Oriental background to attract a primarily white audience. Helen, for example, treasures a floor-length cheongsam that her Mom had commissioned for her from one of the finest tailors in Shanghai. Different patterns of cheongsam carry different meanings. One pattern in "the color of a robin's egg" is "printed with white snow blossoms" (See 2015, p. 72), evoking the frostiness of water, symbolically marking the beginning of a new phase of her life. Helen wears the garment in the club and finds her popularity with customers growing. Seeing this, the club's owner, Charlie, tells the other girls that they should follow Helen's example: "You girls are going to need long gowns or cheongsams like the one Helen wore tonight. I want to see all my glamour girls on the floor between shows." (p. 75). ${ }^{7}$ Charlie does not see the complex stories that Helen's cheongsam can tell, nor the family connection between mother and daughter nor the marking of a passing stage in Helen's life. Rather, he sees only a superficial signaling via a traditional Chinese garment of a reductive message: exotic, foreign, Chinese, and how me might use that message to sell. This wardrobe choice seems to fit into the clichéd criticism in Asian-American scholarship-Asians are trading on exoticism or self-Orientalizing themselves to fit a Western audience's stereotypes about Asians. Edward Said defines Orientalism in his book of the same name "as a Western style for dominating, restructuring, and having authority over the Orient" (Said 1978, p. 3). Orientalism refers to the discourse in which the East is defined and imagined by the West instead of being represented in a way that is true to reality. When we talk about these Chinese dancers self-Orientalizing themselves, this means that they create an Oriental image in Western imagination.

In addition, the costumes and performances also traffic in stereotypes. The dancers' naming themselves "China dolls" has the resonance of self-objectification: they perform as toys that entertain the guests. When Ruby asks Helen to try walking like the women with bound feet (p. 26), the aesthetics they are selling to nightclub customers is traditional Chinese culture. Additionally, the fact that dancing girls are chosen more based on their looks rather than their talents also affirms that their value is reconstructed through the Western (patriarchal) gaze of nightclub customers instead of their talents.

In Ruby, See reveals the conflation of the Chinese culture with sexual exploitation. Ruby appears to epitomize a China doll or a Chinese princess. Her stage name is Princess Tai and she is labeled as "the world's only Chinese bubble dancer," 8 described as being "straight from China," and "when she moves that pale orb just so, visitors imagine they can see all the way to China" (p. 138). In her shows, for example, she sometimes wears an Oriental dress in which her nipples are pushed against the thin silk. Yet, Ruby is actually Japanese-American. Her Princess Taiwan persona is a fabrication, the symbol of an Oriental girl, and a combination of sexuality and exoticism: a combination that forms the foundation of the nightclub's business model.

In many ways, however, restrictions of the nightclub space mirror those of mainstream society in which these Asian-Americans have to perform according to Chinese culture to meet the expectations of the majority. Grace, for example, is born in Ohio where she faces prejudice and familial abuse.

7 The following citations in this form are referred to China Dolls (See 2015).

8 Lisa See most likely creates this character based on the bubble dancer in reality during the time, Noel Toy, who was a star in the nightclub Forbidden City. For more on Noel Toy, see Dexter Waugh, "Forbidden City," in Image Remembers, October 29 (Waugh 1989, p. 24). 
Her father tries to take away her Oriental culture and make her into an "all-American girl" (p. 8). These efforts do not prevent the children at school from making fun of her. At home, she has no way of exploring her own Chinese culture, which is a tradition her father has banned from the house, but her Chinese appearance makes her a target for other children who exclude her. Her move to San Francisco is an attempt to escape her conservative hometown. She discovers, however, that running away from home to a big city does not resolve the problems that her Oriental appearance brings. She is excluded in San Francisco as much as when she was in Ohio. A casting agent who is hiring performers for a big show, for instance, rejects her merely because of her ethnicity. Even though she is a native-born US citizen, he calls her "a regular China doll" (p. 10) and expects her to have an accent. In such moments, Grace's experience embodies the suffering that Asian-Americans endure in American society-a suffering that stems from failing to meet the expectations that Americans have for Asian-Americans.

At the same time, Grace is also rejected by Helen's brother Monroe because he thinks Grace would "never act like a proper Chinese wife" (p. 97). Monroe expects his future wife to follow the Three Obediences 9 and calls her "lo fan" (the derogatory term for "foreigner"). Her difficulties in job or marriage do not arise from her qualifications but because she does not match what others expect from her as an Oriental girl. For the casting agent, she is too Chinese. For Monroe, she is not Chinese enough.

Helen suffers from similar expectations. While Grace's father forces her to become "all American," Helen's family does its best to maintain Chinese traditions. Helen's father represents a traditional patriarchal figure. He insists on retaining Chinese culture, hopes to go back to his motherland, and complains about his sons being too Americanized. He even rejects the offer to be a naturalized American citizen when the U.S. government overturns the Chinese Exclusion Act in 1943 (p. 235).

Even more than his sons, Helen is a constant disappointment to him. He hopes, for example, to get an eighth son because the sound $b a$ (eight) symbolizes good luck. He dislikes Helen because her birth breaks the promise of the eighth son and he loses the chance to brag about it. He also denies the very notion that a woman might be independent. "Marry out a daughter is like tossing out a cup of water," (p. 185) he believes. In his mind, "a woman without education is better than a woman with education" (p. 32, italics original). Besides being excluded from education, women in the family including Helen are not allowed to drive or show their arms and legs. Therefore, Helen, by dancing in a nightclub and exposing her arms and legs, is shameful to her father. "If you dance here, you will be one notch above a prostitute," he proclaims. "Is that how you want people to regard me in Chinatown-as the father of a no-no girl?" (p. 48). His concerns are for his own reputation and family tradition rather than his daughter's individual freedom, interests, and career. Born in a traditional family in a traditional Chinese compound right in the heart of Chinatown, Helen, at 16-years-old, marries into the Kwok family in Soochow, which is a marriage the two families arrange. However, Helen's husband dies not long after the wedding and her family finds her widowed state to be embarrassing and shameful. Helen's father once says her only purpose in life as a widow is to linger on before dying (p. 185). Such a condemnation and such a dismissal shows that her family defines her not based on her own values but on traditional protocol. One time Helen compares her life to the crickets in the emperor's court ${ }^{10}$ (p. 18), referring to the restricted sphere her family and courtyard give her.

The courtyard Helen's family occupies symbolizes the traditional patriarchy and hierarchy in traditional Chinese society. She describes it in this way: "We occupied an American version of a Chinese compound, with four sides, each with two stories, surrounding an interior courtyard" (p. 37). The historical architecture of a compound (siheyuan) often signifies wealth and prosperity due to its layout representing traditional Chinese morality and Confucian ethics. One can tell the hierarchy and

9 The novel mentions that Monroe recited the Three Oediences-when a girl, obey your father; when a wife, obey your husband; when a widow, obey your son. (p. 87)

10 The cricket in the emperor's court is a reference to one of the scenes in Bernardo Bertolucci's film The Last Emperor (1987). 
marital status of the children from where they stay in the courtyard. Helen lives with her brother and parents in the back of the compound, which is the most secluded building in the siheyuan. In addition, the compound seems isolated from the rest of the world by those walls. The courtyard is divided by walls and rooms in a way that kids of different marital status are divided. The courtyard Helen lives in marks a strong contrast to the borderless, restriction-free nightclub.

\section{2. "Then we broke into a simple combination-leisurely and rhythmic, in time with the gentle tune."}

This description of the household as a walled city, turned inward, guarding against the press of outer world, contrasts strongly with a vision that Grace conjures in her mind of the ideal nightclub: a space of "white banquettes, hatcheck and cigarette girls, champagne bubbling in thin-stemmed glasses, men wearing top hats, white ties, and tails, and women swanning about in satin slip gowns cut on the bias that draped over their bodies like whispered kisses" (p. 12). Even though the nightclub is not enticing to the girls at first, it gives them a space to re-imagine possibilities for themselves and their relationship with others. Helen describes her feeling when she first stepped foot in a nightclub: "the place was still a skeleton, but as my mind put flesh on it, I began to see a nightclub like the one in Shanghai where I'd once danced the fox-trot" (p. 20). Clearly, the nightclub in Chinatown is far less developed than nightclubs in Shanghai, but it takes her to the imagination of her hometown and her culture and, most importantly, it becomes a space for her to re-imagine her identities outside her filial boundaries. The nightclub, in this way, provides a canvas from which the women's imaginations can work and a space that allows them to imagine possibilities beyond those offered by either traditional Chinese culture or the oppression of 1930's America.

The nightclub grants Grace an escape from her abusive father and restrictive home and dancing endows her with a flexible lifestyle on which she can make a living. Finally, when she becomes famous, she is not stuck in one nightclub but travels all over to perform at places like the Sky Room, Kubla Khan, Lion's Den, Club Shanghai, and Club Mandalay. ${ }^{11}$ The fluidity and freedom of movement also gives her enough flexibility and open space form her own identity. Her title Oriental Danseuse follows her everywhere she goes and she slowly builds a network beyond her original self. Even when it is difficult for her to find a gig in San Francisco, she can join the Chop-Suey Circuit. "Clubs across the country-mainstream nightclubs—invited us, meaning the Chinese "This" or the Chinese "That," to perform as novelty acts" (p. 260). Nightclubs from all over the country form a fluid network for her to formulate a diasporic identity. Therefore, her travel experience from her little hometown in Ohio to the Forbidden City in San Francisco opens up her world as a performer and artist. Dancing frees her to move around the country and precludes from a fate like her mother's-a prostitute that makes her dad lose face. At the end, she is able to live the life she had dreamed of in Plain City and be an independent woman living with her lover.

The space of nightclubs and Chinatown give Grace hope beyond the little conservative town she is from. Being a Chinese-American, being around many Chinese is not the most comfortable thing for her, yet as foreign as it seems to her, "Chinatown felt frighteningly enchanted in the way certain fairy tales had once left me unable to sleep" (p. 13). Chinatown is a place that could potentially carry some of her hopes and dreams. Her migration gives her the hope of re-starting her life like when someone in Chinatown calls her "lady" instead of "measly girl," "hog face," "Chinaman," or "Little One" when she is in her conservative hometown. In her dancing career, she has been through ups and downs and, in the end, has become an achiever in both life and career since she herself admits, "my life does look perfect: the nice house, the practical blue Volvo, two professional sons, their perfectly adequate wives" (p. 368). While not perfect as she might want it to be, her life is much better than when it was

11 For detailed descriptions and pictures of these nightclubs see Forbidden City, USA: Chinese American Nightclubs, 1936-1970 (Dong 2014). 
in her little town. Her story shows that the nightclub life is not merely a scene to display sexy Chinese girls but a venue for women to escape their restrictions and thrive, which eventually allows her to pursue independence.

The space of the nightclub is also a means for Helen to get out of the cage set up by her family and tradition. She describes herself as having "slept so far out of my cage-out of myself-that I followed Grace like I was the one who was lost and she was now leading the way" (p. 18). When Helen first meets Grace, she feels that Grace is too American and considers her actions unexpected from a Chinese girl. Slowly, though, she feels herself becoming someone like Grace. In the Chinese compound Helen lives in, everything is pre-defined, but the world of the nightclub stays open and undefined for her, challenging the traditional protocol and ideals that Helen grows up with. Helen is told to be a proper Chinese daughter and wife including guarding her reputation "like a piece of jade" (p. 29). To her father, working in the nightclub is like "no bottom to the depths" and would "go to embarrass and humiliate the family" (p. 185). Yet, between hiding in the family courtyard as a widow and going out to work in the clubs, Helen chooses the latter and leaping out of the cage gives her a sense of fulfillment that she never experienced at home. She can finally live on her own like an independent woman.

Furthermore, the nightclubs provide a site where Chinese-American women push their bodies up against ideologies that have discouraged them from openly expressing their desire and sexuality. In nightclubs, the public portrayal of their sexuality and sexiness through dancing is beyond the Chinese tradition or the stereotype of Chinese women. Perhaps as Ruby summarizes, the dancing girls "look simultaneously American healthy and accessible and Chinese exquisite and alluring" (p. 361), which brings exoticism and familiarity along with accessibility and distance at the same time. The way they dance even shocks themselves: "who would have guessed a Chinese girl could move like that? Chinese were supposed to be bowlegged and clumsy. And weren't the women supposed to be submissive?" (pp. 68-69). The dances challenge the stereotypical view of Chinese women-the gentle, submissive, and conservative ones. The sexy dance moves they perform are taking them away from the protocol of traditional Chinese women and, instead, present a blending of Chinese and American cultures. In the finale of one of the shows, they form a conga line and "shake those hips from side to side, and kick! It's the Chinaconga!" (p. 71).

This, perhaps, can be seen most plainly in Grace's description of the group as China dolls. The full text reads: "We looked delicate and breakable-like dolls, like little China dolls. Then we broke into a simple combination-leisurely and rhythmic, in time with the gentle tune" (p. 68). For the dancers, there is something in the nightclubs beyond their superficial exoticization. That something is a relative space of freedom for them to generate their racial and gender identity.

The male characters in the novel including dancer Eddie and the club owner Charlie spin a heteronormative ideal of gender and sexuality in the common representation of dancers' bodies in nightclubs. The novel shifts the gender hierarchy since the feminine body is displayed as a main motive force behind the performances and the nightclub yet men are rendered invisible by comparison. For example, Helen's ex-husband from the marriage with whom her family had arranged dies and does not have a voice in the novel. Eddie is a good dancer, but he is only featured with the girls and is seen as a Chinese Fred Astaire. Later, he becomes a good husband for Helen. Joe is a typical white man, but, in the novel, he becomes a subject to be desired by both Ruby and Grace. These men make appearances mainly as dance partners, life companions, or background characters for the female performers. Women, instead, dominate the central stage and it is their voices that are audible throughout the novel.

Moreover, nightclubs give Asian-American women a space to exercise artistic freedom. Before the war, Ruby made the most popular "Chinese" dancing girl: the Princess Tai that has traveled around, fetching the award for "Best Undressed Doll of the Week" (p. 331). "She just smiled and laughed and flirted. That's what made her Princess Tai" (p. 167). She is featured as a Chinese princess with her grace and beauty. Even though truly Japanese, she becomes a symbol of China Dolls among the 
dancing girl and the Chinatown nightclub community, and she takes pride in it. Ruby's example proves that, in nightclubs, Oriental women can create Oriental versions of the famous Western dancers and actresses as if they could also have the same freedom as Western women. The club owner of Forbidden City, Charlie, introduces Ruby as "our very own Chinese Sally Rand" (p. 160) equating Ruby to an American dancer most noted for her fan dance and balloon bubble dance.

Comparing Ruby to a famous American dancer indicates that, in the space of nightclubs with their dress codes and dances, Oriental women could have a similar degree of freedom and show off their talents like Western women. Moreover, the characters push against this particular kind of Americanization and subjugation to American celebrities by crafting their own separate identities. The fact that Ruby makes more than 10 times as much as office workers make shows that being a dancing girl could render her financially independent. Soon Ruby becomes the headliner of Chinatown and she navigates the fame with grace and confidence. When invited by Helen's father to the one-month banquet for his grandchild, Ruby dresses outstandingly: "in emerald shantung with navy trim and a matching hat with a net veil coming down over her eyes" and shows her gesture like a star: "shaking hands, posing for photographs" (p. 170). Ruby is brought to highlight the embodiment of Oriental and Chinese culture. Later in the novel, we learn that Ruby is a Japanese woman who is prone to be caught during WWII and was considered alien even though she is an American citizen. The nightclub space provides a stage for her fabricated identity to be created by the club owners and herself.

She is feeding Joe the China Doll figure that he yearns for in his consciousness even though she is actually a Japanese person. Though fabricated, Ruby makes herself into a symbolic Oriental girl, which is the combination of sexiness and exoticism. Therefore, Joe's attraction to Ruby is more from his fascination of the exotic Orient and her sexiness. One time when coming back from serving in the war, Joe says to Ruby, "You're a succulent dish, baby," (p. 203). Seeing Ruby as a delicious dish is objectifying her to something that the white superior can savor and enjoy. Therefore, his desire for Ruby comes from his Orientalist mindset of possessing a China doll. To maintain Joe's interests, Ruby has kept from him the fact that she is Japanese. When the fact is revealed and Joe asks why, she says, "(y)ou wanted a China doll. I gave you a China doll" (p. 208). Ruby uses his Orientalist mindset to her own advantage in order to prove her American background and wins his heart. In the end, her lies hit him very hard and make him feel betrayed. Rather than simply self-Orientalizing herself, Ruby willingly manipulates the Orientalist paradigm and re-asserts her own position as an Asian-American.

Furthermore, the nightclub becomes a space away from segregation, which is a contact zone for people of various ethnicities to mingle and a space that blurred the boundaries. The friendship between the three main female characters proves this. The nightclub and its dancing bring them together and, even with much prejudice and struggle, they still dance in sync after many years. Nightclubs fuse their cultures to a certain degree. When Grace grabs Ruby's hands with excitement, she thinks "what was it about these girls and all their touching?" (p. 36). The interaction between Helen and Grace is definitely a process of East-West cultural exchange even though they both look Chinese. One time, for instance, Helen says to Grace, "If you can teach me how to tap, then I can certainly teach you how to eat like a proper Chinese" (ibid.). For the dancers, there is something in nightclubs beyond their superficial exoticization. That something is both their creativity, their freedom, and their connection with each other.

In China Dolls, nightclubs become the place where boundaries are softened during the war. It becomes the only place where Japanese are not as excluded as they are elsewhere. Even when America launches an anti-Japanese campaign, the club owner Charlie says, "If any of you is Japanese, who cares? You're my glamour girls. You work for me" (p. 187). Moreover, he is not alone among club owners who take the all-inclusive approach. They care about entertaining their guests and making their business prosperous more than they care about the ethnicities of the entertainers and performers. Therefore, Ruby had been able to maintain her fame and popularity for a while before being arrested. She "performed - enticingly lit by her blue spotlight-laughed and joked with the boys, and generally kept up her Princess Tai façade, but she was inconsolable at home" (p. 187). The nightclub is where 
she could gain her pride and confidence and where she could hide her fears and real identity even though deep inside she knows that her heritage makes her feel threatened.

While these dancing girls sustain their pride by performing in nightclubs, the dancing girls also serve as a source of comfort and an expression of longing for the soldiers who go out to fight in the war. They send their signed photographs_-"dreaming of you, forever yours, Princess Tai," "To a swell guy, love always, Grace," or "May you stay as sweet as you are, love and kisses, Ida" (p. 199). These words show their genuine sentiments for the soldiers. These girls have reminded the soldiers of home and peace in the midst of the brutal war. However, many of the dancing girls turn into victory girls during the war in order to exhibit their patriotism. They offer companionship and often sex to the soldiers who served in the war. While these dancing girls seldom have intimacy with their clients when they are performers, they serve as comfort women when soldiers return. The boundaries of nightclubs change from a more protective arena for the women to a place that offers comfort and encouragement for the servicemen in the war.

Besides being a place for performers and service members, nightclubs also become a shelter for many people during the war. "Clubs like the Forbidden City gave people a place to blow off steam, celebrate, share experiences and trade stories, and laugh away their staggering dread of what might come" (p. 190), which a writer for Variety calls as "escapology." It becomes one of the very few happy places when everywhere else is disastrous and haunting. Therefore, during the turbulent wartime, the nightclub becomes a place of peace and hope. ${ }^{12}$

Although nightclubs become a relatively free zone for the female performers to escape from their restricted spheres and traditions and for them to exercise some artistic creativity and a new identity and for them to mingle, it imposes its limitations including either gender-based or ethnicity-based. The nature of a "contact zone" is partially exploitative since it fits into the discourse of Orientalism, which has been discussed earlier. The creativity of their performance is limited because it is largely determined by the club owners and directors. Being a dancing girl in Chinatown nightclubs often would not get them wherever they want to be, but only someone who represents the Chinese culture. Growing up from a conservative American town dominated by whites, Grace's dream is also to be like the Western movie stars instead of becoming an Oriental star, which she ends up being. When she replaces Ruby to be a star in a Hollywood movie Aloha, Boys!, she finally finds herself transformed. At that point, she is no longer a China doll performing in nightclubs but rather she finds herself an extraordinarily beautiful woman (p. 211). Yet, even in the movie, she cannot completely be what she wants to be since she had wanted to be a Chinese Eleanor Powell who is an American dancer and actress she admires. Yet she is now known for, in her own words, an "Oriental mishmash" (p. 231).

In general, the novel grants a celebratory tone to the dancing girls' fight for their own space and identity. The author, Lisa See, has assigned Grace as the main narrator and given her the authority to comment on these social prejudices. At times, she would respond to those assumptions bravely. For instance, when Monroe explains why he could not marry her because she would never be a proper Chinese wife, she asks, "have you considered that you might be too Chinese for me to marry?" (p. 4). Furthermore, she notices Caucasian customers' comments on the Asian American performers' Oriental look and American voice, saying they "were trying to be polite and complimentary but were really showing their ignorance and prejudice" (p. 4). In the novel, Grace is neither a traditional Chinese girl like Helen nor is she someone who has to assert her Chinese culture like Ruby. Instead, she is established as fierce, brave, and full of integrity and sharp observation. Grace and Ruby's fight over a white man signifies the fight between true love and the stereotypical East-West relationship in which Ruby represents a sexy China Doll to the white man. Grace falls for Joe at first sight and she persists in her love until the end. Joe and Grace experience a lot of ups and down, but eventually, when Joe

12 In reality "the war years were good years for San Francisco night clubs, and so were the immediate post war years" (Seligman 1989). 
comes back from the war, he comes back to her and she "[wins] the prize (she'd) always wanted: love" (p. 347). That moment marks the final victory of her persistence and strength—beyond the fights over friendships and love.

\section{3. "All of us, in our own ways, were doing the best we could to erase who we were."}

The nightclub proves to be a free open space for the dancing girls to express their sexuality and explore their identities, but it may not be transformative for their lives on the whole. In the end, Helen returns to a traditional mother figure who keenly wants a son and then takes care of her son. In her narrative, "if Chinese people could have seen us together, they would have offered the supreme compliment for motherhood-that I loved my son like a cow licking her calf-but we never encountered proper Chinese" (p. 305). She herself takes pride in motherhood and sees it as her priority by the end of the story. To Helen's father, a woman's duty is to get married and have children. Eventually, they grow up and take care of their parents. This Confucian belief is passed along to Helen. In addition, she cannot change some of her conservative beliefs like her stance against mixed-race children. Moreover, near the end of the novel, Helen's granddaughter, Anne, visits and interviews Grace meanwhile criticizing Grace for perpetuating Asian stereotypes. That criticism represents her stance as an Asian but failing to appreciate how those stereotypes can be (gainfully) re-appropriated by Asian-Americans if they so choose. She supports her own Chinese culture being kept intact and not interpreted wrongly in America. The Chinese patriarchy and tradition in Helen's family does not actually change no matter how hard Helen tries to resist it. The nightclub life for her is only a temporary escape from her traditional courtyard life. Yet, she can never entirely get rid of the constraints her Chinese upbringing creates.

At the same time, the novel shows that, even though nightclubs could function to break some boundaries between ethnicities, Asian-Americans still face alienation and discrimination in society. Most Asian-Americans in the book show strong resistance to being labeled as Chinese. In her very first interview to be a performer, Grace says, "I'm not from China. I was born here" (p. 9), but the explanation does not rule her out from being a China doll in the interviewer's mind. During the war, Ruby distinguishes herself from Japanese natives, saying "I'm not an enemy alien. I was born here, and I'm an American citizen" (p. 189). Eddie, the club manager, resists falling into the stereotype. He says, "I don't want to be the Chinese Fred Astaire" (p. 135). Instead, he wants to "be recognized for who $I$ am and for what $I$ do" (p. 135). His example shows that someone of Asian descent is often expected to represent Chinese culture, which, in some way, subjugates their own values and identity. Furthermore, their Chinese faces often bring them accusations that are based on stereotypes rather than fact like "Chinese men are oversexed, and we're going to rape white women and pollute the race" (p. 135). Because of the stereotypical American views toward Chinese people during the period in which the novel is set, finding jobs as Americans of Chinese descent would be "as futile as plowing the sand and sowing the waves" (p. 136), as Helen describes. Through these examples, the author shows the difficulty of Asian Americans in American society. Despite being born and raised in America, Asian-Americans' skin color has become a stain throughout various periods in American history. As Grace says, she has been beaten by her skin color her entire life (p. 158).

Ruby's restrictions, on the other hand, are revealed later in the novel during World War II. The shift of Ruby's fate shows how the nightclub, ultimately, cannot provide the necessary freedom to escape the essentialist categories and prejudices of larger society. Once the war hardens the boundaries between us and them, then the fluidity that Ruby has enjoyed and the freedom of the Princess Thai character is shattered. She is Japanese and, therefore, the enemy. It does not matter that she was born in the US. It does not matter that thousands of nightclub patrons thought of her as the ideal Chinese doll. All that matters is that her parents were Japanese-and that is enough to land her in detention. WWII becomes a watershed moment in the novel in terms of the relationship between the three girls and the popularity of Chinatown nightclubs. To many, the breakout of WWII signifies a moment of fear and anxiety. The novel includes the fact that President Roosevelt signed the executive order excluding any or all 
persons suspected of being enemies hailing from Japan. Therefore, many Japanese people from every walk of life were sent to internment camps overnight, as the novel describes: "the next day, 250 enemy aliens, mostly Japanese, were rounded up in San Francisco and sent to Bismarck, North Dakota" (p. 193), and subsequently, "General Dewitt issued instructions that all people of Japanese ancestry living in San Francisco would be wise to voluntarily evacuate inland" (p. 193). This moment suddenly draws a clear line between friends and enemies with American officials showing hostility towards the enemies.

What is confusing, however, is the definition of enemy. If the Japanese is the main category of enemies, would that include Japanese-Americans? The posters all around address "To All Japanese" and do not distinguish between alien and non-alien (p. 193). Categorically, Japanese-Americans would be on the list of enemies and, therefore, would be arrested. Ironically, Japanese-Americans like Ruby do not identify themselves with being Japanese as much as being American to the extent that, during the war, she claims confidentially, "I'm not an enemy alien. I was born here, and I'm an American citizen" (p. 189), "it was our national job to hate the Japs" (p. 355). However, she was not exempted from being arrested and was sent down to the internment camp. Ruby's identity confusion and conflicts between her identity and her political position prove the problems in how "enemy" was defined during the war. However, whether one was Japanese or Japanese American, one was seen as an enemy and was ordered out of the Bay Area, "with the result that several dancers from the Sky Room disappeared and had to be replaced" (p. 195).

During the war, the American authorities' treatment towards Japanese is like treating the other as the inhuman. In the internment camp, Ruby is asked a series of questions every day as if she were naturally a traitor because of her ethnicity. The scene wherein the doctor examines the girls shows the inhumanity of the punishment system towards Asian immigrants during the war. "A table with stirrups sat in the middle of the room, as ominous as a torture device run by demons in the afterworld" (p. 311). The doctor keeps threatening the women while examining, saying if he finds anything he would send them to an institution to treat them. Moreover, the doctor is quite biased against Ruby, saying, "I don't even need to examine you to know what I'll find," and continuing, "someone who's as infected as you're bound to be is facing forcible detainment until the end of the war" (p. 312). The doctor shows no sympathy towards her but instead fully supports and is a part of the cruel system that excludes and subverts Asians and women.

Even after the war, WWII remains a traumatic memory and the Pearl Harbor incident remains a sensitive topic between Americans and the Japanese. When Charlie opens up his new bar, China Doll after WWII, he makes it very international by incorporating cultural elements from various countries. The author calls it a "regular United Nations" (p. 329). Yet he avoids anything Japanese. Instead, he labels "his glamour girls 'Chinese' to protect them" so that "no one would be reminded about the dropping of the atomic bombs" (p. 329). It shows that one cannot be too careful about avoiding the topic of Japan even after the war is over.

The war hardens the borderline between good and bad, friend and enemy, American and Japanese. During that period, the authorities help American citizens recognize the Japanese enemies. Therefore, "the magazines offered diagrams and photos titled 'How to Tell Japs from the Chinese' and 'How to Tell Your Friends from the Japs'" (p. 188). In addition, the descriptions demonize the Japanese, claiming they have "dogmatic assertions" and "insistence on pushing ... arrogance in your face" (p. 188). Such distinctions, drawn by Americans between the Chinese and Japanese and promoted during the war, have made it even harder for the two countries to be friends.

Ruby is one of the victims during the war. She lives a lie before the war-a Japanese woman acting as a Chinese princess in the clubs and seducing Joe as a China Doll. However, the war unveils all the lies. She is caught and sent first to the Relocation Center and then to the internment camp. The 17 months of confinement and tortuous camp life make Ruby think that, "I've been robbed of my life" (p. 263). Moreover, her life in the Topaz War Relocation Center is described as helpless and unreasonable. 
I ask myself, why do they hate us so much? What did I do that was so dreadful or unforgivable that they need to lock me up in a place like this? There is no lower helplessness than realizing you've lost control over every aspect of your life... But if we ask the authorities how long we'll be in here, the answer is NO ANSWER! (p. 272, italics following quotes)

Innocent people like Ruby are turned into victims without justifiable reasons but only because of their heritage about which they can do nothing. To Japanese-Americans like Ruby who are born and raised in the United States, there is confusion about who to be loyal toward. While Ruby still identifies America as her country and fights for it, her brother says to her in the internment camp: "you're going to fight for them after everything they've done to our family? After putting you in this place?" (p. 223). His question shows Japanese Americans' confused patriotism during the war. Ruby says, "I loved the United States. It was my home, but inside I was so angry. So angry about everything" (p. 224). First-generation Japanese immigrants, Issei, are forced to go stateless during the war since as they have not had the right to become American citizens. Yet, all of a sudden, they were asked to declare allegiance to the U.S. If any Japanese descendants answer "no" to either being faithful to the U.S. or being willing to serve in the U.S. armed forces or in combat duty, they would be classified as a "no-no boy/girl."

Meanwhile, the American culture becomes a privilege that the characters celebrate but have a hard time internalizing as their own identity. Many Chinese immigrants endure humiliation and discrimination while settling in America and naturalizing as Americans. Therefore, seemingly, Chinese Americans enjoy the privilege of being born as Americans, as Helen's brother summarizes: "we don't have a desire to be American. We are American" (p. 3). He also enjoys the freedom to state his view publicly as an American. In addition, despite the fights and struggles the three girls have in the novel, they all want the American life even if that means erasing who they were (p. 301). However, the American background of Asian-Americans does not always grant them the same privileges as white Americans since regularly they are not categorized as mainstream Americans but rather by their descent, their skin color, and superficial assessments of their appearance. At the Forbidden City, total strangers asked Grace if they could touch her because they had never touched an Oriental before (p. 292). Despite being home in America, they are considered aliens, different, the other. These tensions raise doubt around the loyalty to America and insistence on an American culture. Grace observes, speaking about Eddie and Monroe, "both of these men-like my father-were enthusiastically American, but what had it gotten them?"(p. 288).

Because the main characters in the novel are considered different and alien, they try hard to erase their ethnic identity and highlight their American background. Perhaps they think that doing so would draw them closer to the majority of the American population. When Joe proposed the idea of marrying Ruby, he received a letter from the State Bar of Nevada stating it was a crime for a Caucasian to "inter-marry with any person of the Ethiopian or black race, Malay or brown race, or Mongolian or yellow race" (p. 192). The extreme racism perhaps is one reason that Asian girls try hard to resist their Asian identity. To Ruby, Joe is very American (p. 193) and she thinks that marrying Joe would prove her American identity. Ruby's eagerness to consolidate her American identity arises from her insecurity about her own identity that "she seems especially suspect because she'd masqueraded as Chinese, dancing in a nightclub frequented by servicemen" (p. 193). As Ruby observes, "all of us, in our own ways, were doing the best we could to erase who we were" (p. 301). Since their Asian looks and cultures have brought them discrimination, alienation, and tortuous treatments, they have resisted their ethnicity and heritage until realizing that that resistance may be unrealistic. In the end, the freedom they achieve is limited and becomes circumscribed by both the personal choices they make and larger societal pressures.

The friendship between our three female protagonists is challenging during the war. Grace struggles between the thought of Ruby as an enemy and a friend. "Ruby was Japanese. I was living with the enemy. But she wasn't the enemy, I argued with myself. She was my friend. But was she, really?" (p. 180) This passage shows Grace's unrest, as she is hoping to trust her friend yet she 
cannot help the fear and distrust inside her. In order to control her emotions, she has to give herself affirmations in her head: "I repeated, She's my friend, my friend, my friend" (ibid. emphasis original). Grace shows her sincerity toward Ruby. She is deeply worried about Ruby's safety when the war breaks out and saddened by the news that she is taken away. Ruby's presence is everywhere in their shared residence when she is interned. Yet, the voices from the public and authorities sway her belief in her friend.

\section{Conclusions}

At the end of the novel China Dolls, Helen's granddaughter, Anne, asks Grace questions that almost sound like accusations, "How do you feel being billed as an Oriental performer, dancing in an Oriental Club?" "Did you know you were perpetuating Asian stereotypes? How could you dance at a place called the China Doll or even tolerate being called a China doll?" (pp. 371-72). Grace thinks, "why do these young people make such a fuss about this? It's not like saying Jap —like Helen and Joe always said—or colored or something even worse. Or is it?" (p. 372). This statement invites us to rethink the issues about stereotypes and self-Orientalism of Chinatown nightclub dancing girls. When Rachel Chu claims her success at the end of Crazy Rich Asians, criticizing the stereotypes of Chinese societies, Grace Lee in China Dolls calls into doubt on the issues of self-Orientalism and East-West stereotypes.

Lisa See, by focusing on the Chinatown nightclub experience of the dancing girls, shows the dynamic between static local places and mobility, which provides a portrait of the heterogeneity that often characterizes the immigrant experience. Her novel challenges the binary world between stability and mobility in the Asian-American identity instead of establishing the dialectic of the two. Discussing the place-based gendered identities in her Asian American/Asian diasporic work compels a rethinking of boundaries and locales. This paper on the Chinatown nightclub and its dancing girls calls for a shift to redefine the Asian-American literary landscape through the perspectives of place, space, and belonging.

Funding: The Department of Modern and Classical Languages at University of Houston has sponsored my archival trip to San Francisco.

Acknowledgments: I wish to thank the San Francisco Public library History Center and its staff who generously provided help locating useful images and newspapers. I also want to acknowledge Steve Pijut, the associate director of the writing center at Washington University in St. Louis, who has provided useful feedback for my paper. In addition, I thank guest editors Robert Tally and Eleonora Rao for their interest in my topic.

Conflicts of Interest: The author declares no conflict of interest.

\section{References}

Anderson, Elijah. 2011. Cosmopolitan Canopy: Race and Civility in Everyday Life. New York: Norton.

Bachmann-Medick, Doris. 2016. Cultural Turns: New Orientations in the Study of Culture. Translated by Adam Blauhut. Berlin: De Gruyter.

Buford May, Reuben A. 2014. Urban Nightlife: Entertaining Race, Class, and Culture in Public Space. Brunswick: Rutgers University Press.

Crazy Rich Asians. 2018. Crazy Rich Asians. 2018. Directed by Jon M. Chu. Los Angeles: Warner Bros. Pictures.

Dong, Arthur. 2014. Forbidden City, USA: Chinese American Nightclubs, 1936-1970. Los Angeles: DeepFocus Productions, Inc.

Friedman, Susan Stanford. 1998. Mappings: Feminism and the Cultural Geographies of Encounter. Princeton: Princeton University Press.

Said, Edward W. 1978. Orientalism, 1st ed. New York: Pantheon.

See, Lisa. 2015. China Dolls. New York: Random House.

Seligman, Craig. 1989. Film recalls S.F. nightclub that opened door for Asian performers. San Francisco Examiner, November 15.

Waugh, Dexter. 1989. Forbidden City. Image Remembers, October 29. 
Xu, Wenying. 2015. Fae Myenne Ng's San Francisco Chinatown as a Social Space of Legal Discrimination. In Asian American Literature and the Environment. New York and London: Routledge, pp. 30-46.

Zhou, Xiaojing. 2014. Cities of Others. Reimagining Urban Spaces in Asian American Literature. Seattle and London: University of Washington Press. 